\title{
APAC in Hungary ${ }^{1}$
}

\section{TIHANYI Miklós²}

\begin{abstract}
The author examines the Hungarian features of the APAC units. Study visits were carried out in four correctional institutions and interviews with the chaplains were recorded. According to his conclusions we can find places in Hungary called APACs or religious units where the main element of the reintegration is religious education. The difference between the two kinds of units are not significant. Many of the features of the APAC methodology are partly or entirely missing from the Hungarian practice, though civilians are present but not to the extent they should be; also, there is a great difference regarding the quality of cooperation with them. There are significant handicaps in the selection and promotion system. They totally lack the progressive regime, the family support, and the legal help. The regulator gratuitously reduces the time that can be spent there to 3 years. In case of long sentences this time is not enough to counterweight the negative effect of prison life.
\end{abstract}

Keywords: faith-based prison, APAC, prison chaplaincy, religious unit

\section{The Background of the APAC Methodology}

The APACs (Associação de Proteção e Assistencia aos Condenados - Association for the Protection and Assistance of the Condemned) are entities of private law, with legal personality, allowed by Criminal Procedural Code, to assist the aim of social reintegration set by penitentiary institutions. ${ }^{3}$ Three main goals can be defined that APAC strives to reach. 1 . To promote the humanization of prisons, without losing sight of the aim of punishment. 2. To prevent recidivism of crime. 3 . To offer alternatives to recover the convicts.

APAC has a history of more than 20 years in Brazil. The spiritual basis of APAC is Christianity. Therefore, one of the main theoretical principles is the attitude to crime and criminals, which can be concluded as follows. "Crime is crime, a criminal is a person. The guilty person is not the same as the crime itself." "Kill the crime to save the person." - declares APAC's philosophy. ${ }^{5}$ The methodology is based on this and as a result APAC is not purely a Christian moral education or evangelism but together with

\footnotetext{
The work was created in commission of the National University of Public Service under the priority project PACSDOP2.1.2-CCHOP-15-2016-00001 entitled "Public Service Development Establishing Good Governance" in the István Egyed Postdoctoral Program.

2 TIHANYI Miklós, PhD, Assistant Lecturer, NUPS, Faculty of Law Enforcement, Public Safety Department orcid.org/0000-0003-2692-5389, Tihanyi.Miklos@uni-nke.hu

3 Sabbatelli (2015)

4 Draxler (2013) 57.

5 http://www.fbac.org.br/index.php/en/how-to-create/philosophy-of-apac
} 
these a method of reintegration that opens a door for the inmate and helps them going through the road. If I wanted to use an image from the Bible I would say APAC shows the narrow path that leads to Jesus and guides inmates during the journey. This is considered to be a healing process. Therefore, inmates are called "recuperandos" or people who are recovering. According to the creators of the APAC philosophy, committing crime stems from a damaged concept in the depth of a person's soul. These can be the mother-, father-, self-, or God-concept. Restoring the God-image has a healing effect on people. By achieving this all the other concepts improve.

Social reintegration as a final goal cannot be achieved without the involvement of the community where we want to reintegrate the person. In this case this is the society and the starting point is the smallest unit, the family and the respective community where the inmates came from. ${ }^{6}$ Therefore the APAC methodology relies on the family to a great extent besides the voluntary organizations and their members. Apart from rare exceptions only those can take part in the programme whose family live near the prison and agree to cooperate and contact them regularly. It is an important recognition that family can be key to the recovery and the failure alike, so APAC do not lack the treatment of the families. ${ }^{7}$ In line with this they offer various services and treatment related programmes to the families. The volunteers are the people who lead the recuperando through the process of healing. This is why APAC cannot be identified with a prison mission which can be case-by-case or regular spiritual occasion or education. Here volunteers follow and lead the inmates' and their families' life, moral, spiritual, and sometimes physical improvement. The key principles of APAC are respect, trust, responsibility, and self-respect as these values are able to restore the damaged selfconcept. This is the first step to re-establish the God-concept. APAC also functions as a family where the recuperando meets the natural values of unconditional love, trust, respect, and responsibility. Later they can practice these values in the course of being released and as a recovered person.

\section{The Spread of APAC and Other Programmes Based on Faith-based Education}

The first APAC section in the Western world was opened in Verne Prison in Dorset, England in 1997 February. It took the Kairos movement, which had been operating in the US since 1976 and managed the treatment of inmates and their families, as an example. Kairos is entirely controlled by bishopric. Between 1997 and 1999 the units operating in Verne were called Kairos-APAC. Later the programme continued its activities with the name Kainos community. ${ }^{8}$ One of the well-known names of the programme is Challenge to Change applying 5 learning methods for the education of inmates: 1. Induction. 2. Community life. 3. Focussing. 4. Social relationships.

Takács (s. a.) 6.

Roszík (1998)

Burnside-Loucks-Adler-Rose (2011) 
5. Citizenship. In order to reach their aims, they used pro-social modelling, team work, meetings as tools. The evaluation of the programme efficiency showed that acts against the order of the correctional institution and the rate of recidivism have dropped significantly. ${ }^{9}$ The first American APAC also opened its gates in 1997 near Houston, Texas in prison Jester II. In the subsequent years APAC units opened in Swaleside, Highpoint North, Highpoint South. After this, similar units opened in Australia, New-Zealand, and in numerous European cities in a row. Today we can find the programme in Germany, Bulgaria, Latvia, Norway, and in Hungary, of course.

The faith-based restorative penal programme works under the name "Sycamore Tree". The name stems from the bible story in which Zaccheus, the tax collector, climbed a sycamore tree so that he could see Jesus better. When Jesus noticed him and asked him to come down from the tree because he was going to stay in his house that night. Zaccheus was very glad that Jesus talked to him and stays in his house. He converted and vowed that he would give half of his possessions to the poor and anyone he cheated, he would pay back the sum fourfold. Those who witnessed were shocked by Jesus staying with a sinner. Jesus' response was to declare the conversion and absolution of sinners. ${ }^{10}$

In the background of this story is that tax collectors of that era in Israel collected the taxes levied by the Roman emperor which did not make them popular with their fellow countrymen because they had a good reason to suspect collaboration. Though what really made them despised and guilty in the eyes of others was that their income came from over taxation. Tax collectors demanded and collected more then the emperor asked for. They made their fortune from the extra they gauged out of people. When Zaccheus recognised that it is a sin to oppress the poor, he did not only give up his job but gave a fourfold compensation. The Sycamore Tree programme is based on the biblical example of restorative justice. It can be summarised as a method that aims to make the perpetrators understand the effect their act had on the victim, their family, and the society. Meanwhile they strive to make sinners accept their personal responsibility as well as make them provide compensation. The programme is assisted by voluntary trainers and mediators and works on the basis of a six-step methodology: 1. Taking the Zaccheus example they discuss what restorative justice means. 2. Taking responsibility. They talk about the effect of their crime on the victims, themselves, and the society. 3. Confession and penitence which covers the expression of regret in words and via actions. Listening to the stories of the victims is also a part of this stage. 4. Reconciliation. Discussion on what advantage it will bring to the perpetrators, the victims, and the community. 5. Planning what steps to be taken after the sin is recognised and admitted. 6. Symbolical restoration, in which regret can be expressed via a letter, poem, or other piece of art. When these are accepted, it symbolises the acceptance of the

After two years, recidivism was at a $35 \%$ rate in contradistinction to the $68 \%$ rate on a national level. Furthermore, only $13 \%$ of the repeaters ended up in prison again. Cf. Liebmann (2011)

10 Lk. 19, 1-10. 
apology. Compensation itself can be included at this point. ${ }^{11}$ Although the "Sycamore Tree" programme aims to influence via Christian principles, it is open for everyone: believers and non-believers, or those who have a different religion.

\section{The APAC and Other Religious Units Implemented in Hungary}

The first APAC was established in 2008 in the Vác Strict and Medium Regime Prison. The Hungarian Prison Fellowship (Magyar Testvéri Börtöntársaság) initiative was accommodated by Gyula Vatai, the head of the correctional institution. Previous to this, the Community had made and broadcast the Hungarian version of the film entitled Love is not a Luxury addressing senior management of the prisons. The film presents the work in the APAC prisons in Brazil which made the head of the Vác Prison interested. The other key figure of the later programme was Mrs Tamás Csuka, prison minister. Though APAC has its roots in the Christian majority society, we can state that the theory and the methodology is of ecumenical approach, there are no elements that would divide Catholics and Protestants. Later two more units were opened, one in the Mélykút women's unit of the Pálhalma National Prison and another in the Tiszalök National Prison. At first the units were established on the grounds of general legal authorisation which enables prisons to run units that satisfy special needs. The first regulation on APAC was only issued in 2014 when in Directive 53/2014. (XII. 23.) OP the relevant rules of operation and the tasks related to them were concluded by the Director General. This meant a great step forward because it provided legal validation for the operation of the units. The directive clearly shows that they took into consideration or even relied on the actual regimes. However, at some points there are significant discrepancies from the original APAC spirituality. The 2015 modification of the 2013 Penitentiary Code mentions for the first time the term of religious units which does not have too much to do with the original APAC regarding its nature. The regulation is quite succinct and defines the practice of religion and the facilitation of family relationships as aims. It also mentions their intensity and the rules of admittance and the rules of the termination of stay. It practically ensures the framework of the religious units. Filling it up with content is the task of the penitentiary system. In 2017 Directive 24/2017. (II. 14.) OP was issued which disposed on the execution of reintegration tasks regarding inmates in units for people who need special treatment or other special units. Its fifth chapter deals with the religious (APAC) units. The title is a really talking one. It puts an equal sign between the religious units and the APAC. The regulation follows the content of the one in 2014.

11 Liebmann (2011) 


\section{The Operation of the APAC and Religious Units}

Despite the fact that there are APAC quarters in Hungary, the Penitentiary Code instead of using this term calls them "religious units". There can be two possible reasons behind this. One might be that the regulator tried to find a Hungarian equivalent for APAC and in lack of a better option took one, though the most descriptive, of its qualities and without damaging the original content found an expression for it. The other reason may be that there are significant differences between APAC and its Hungarian implementation so the regulator felt it necessary to call it in a different way. In the rest of this study I am investigating how much the original principles of APAC were implemented in the Hungarian correctional institutions.

Religious units offer the widest range of chances to practice one's religion alone or in company. Moreover, there is an opportunity to do that with one's own family. The religious unit among the special units is a novelty in the Hungarian penitentiary system. Units like this can operate where there is an agreement on collaboration between the respective institution and the religious community which allows it. This kind of regulation declares the autonomy of the churches and their privilege to choose their tasks within the framework of the rules set. The aim of running religious units is to facilitate reintegration by practising religion and by strengthening family ties. Any inmate who fulfils the requirements laid down in the Code can join the unit regardless of their religion if they accept the regime, the daily routine, and the rules concluded in the "Regula" provided the Admittance and Imprisonment Committee accept their application. ${ }^{12}$

The "Regula" is undoubtedly a component taken from the APAC which can be found in the religious units though they are not called APACs. The main feature of this list of rules is that it is formed by the inmates. In the APAC of Vác city, which has been an example for all the other similar sections, the wording was ready in 2009 but it is not a closed, final version. It is suitable for being tailored for the needs of everyday life in the future. ${ }^{13}$ It can be modified with common consensus. This gives one of the pillars of its legitimacy. The other pillar is the fact that inmates join and follow the rules voluntarily. This set of rules defines the residents' expectations towards themselves and their way of life. In prison environment where the Penitentiary Code is the internal regulation to obey it is practically a competing norm. The inmates in these units cannot entirely avoid being under the effect of the Code. It would only be possible if the religious and APAC units formed a totally independent system, just like the way it was achieved and is seen in South America. However, with the present solution in the absence of an independent regulation they live in the cross section of the two totally conflicting norm systems. Christianity similarly to all other faiths builds on the retaining power of its community to a great extent. The "Regula" actually concludes the basic values and rules of this community. The rules that were accepted with a consensus

\footnotetext{
12 Bv. tv. 96. § (1), as well as 109/A § (Penitentiary Code).

13 Draxler (2013) 62.
} 
strengthen the positive values and the feeling of belonging together. The "Regula" consists of a preamble, establishment of principles, and an afterword. The preamble describes the necessity of the document while the main part is based on lessons of the Bible and the Ten Commandments. Apart from the general expectations, it is also essential to conclude the concrete regular duties of the people accommodated there as a community such as the rules of prayers or the principles to follow regarding the relationship between them or the order in the cell and the religious unit. The APAC regulations of the Vác Strict and Medium Regime Prison became a sample for other similar units. When we get a nearer view of it, we can make the following statements. 1. It is based on two pillars. One is as Jesus said: "You shall love the Lord your God with all your heart and with all your soul and with all your mind. Love your neighbour as yourself. ${ }^{14}$ The other is what was interpreted this way by Paul: "So now faith, hope, and love abide, these three; but the greatest of these is love. Pursue love." 15 Both of the two pillars emphasize one common point which is love. These are actually principles number 5 and 6 out of which respecting one another can be deduced. Here the word respect covers many dimensions: respecting the prison staff, respecting the responsibility for themselves and others, managing conflicts in a peaceful way. All of these finally form them to behave as a community and accept one another as brothers. 2. Taking the Ten Commandments as a basis sets forth a set of values which establish a peaceful life together. 3. It requires a daily routine or rather a way of life which clearly demonstrates the values typical of Christianity.

There are legal requirements that inmates have to meet in order to be placed in the religious units which are as follows. 1 . There are maximum 3 years left until they are expected to be released. 2. The convict accepts to comply with the operational rules in a written format. 3. And finally they are recommended by the reintegration officer who also acquires the opinion of the chaplain. ${ }^{16}$ Only those are admitted to the units who successfully go through the selection process. The opinion of the chaplain is of great importance in this question. During the selection process it is also obligatory to take the eligibility criteria into consideration that is supported by the Hungarian Prison Community and Brotherhood. These require that the inmate should work or take part in a form of education; have a regular and decent contact with the family; the family should have accommodation within $100 \mathrm{kms}$ from the prison; and the family should take on appearing at visitor receptions twice a month and also visit the inmate regularly. ${ }^{17}$ Other factors that are looked at before someone is admitted are the crime that was committed, the sentence, the time left, the criminal proceedings in progress against them, their efforts for the community, and the behaviour of the particular inmate. ${ }^{18}$

\footnotetext{
Mk 12, 30-31.

1 Cor. 13, 13.

Bv. tv. 109/A § (2) par. (Penitentiary Code).

7 24/2017. (II. 14.) OP szakutasítás a sajátos kezelési igényủ fogvatartottak számára kialakított és az egyéb speciális részlegeken elhelyezett elítéltekkel kapcsolatos reintegrációs feladatok végrehajtásáról 76. pont. [Directive on the special reintegration tasks related to convicts in special units. Sec. 76.]

18 Ibid. Sec. 77.
} 
Stemming from its nature the institution of this kind of units was established for people who have a certain faith. Obviously, as data regarding one's religion is considered to be sensitive data, the truthfulness of the declaration about it cannot be investigated. The final decision on admittance is made by the Admittance and Imprisonment Committee. In this case the decision is not dependent on the chaplain's opinion but of course it is taken into account. Actually, the chaplain does not even make a formal suggestion because it is the instructor's task. Interviews carried out in religious units of correctional institutions show that chaplains agree with this way of decision making because the inmates' presence and behaviour at events connected to religion is not an adequate basis to be judged. Chaplains tend to support the admittance of those who regularly join religious events and no concern occurs about their behaviour. In fact, this is a minimum requirement system. On the other hand, in the Vác city APAC, the inmates themselves can make suggestions on the persons who should be admitted. We could easily suspect that they want to involve mates in the programme they would like to play booty with. The reality is that examples until now have shown that they choose those they consider to be cooperative and open. This solution strengthens the atmosphere of trust and increases the person's self-esteem. Naturally, they do not leave out the official admission process but this informal procedure facilitates the integration. In the protocol of the APAC sector of Pálhalma, the inmate's application is passed to the chaplain by the instructor. The chaplain's task is to give his opinion. The chaplain takes into account whether the requestor attended the religious events regularly or not. Besides this, requestors have to write a motivation letter in which they explain why they would like to be in the units and a personal interview also takes place. Then the applicant has to take an "exam" to prove they know the rules in the "Regula" as they need to be aware of what values and rules of behaviour they will have to observe in the future. Finally, the inmate's family have to take on that they will regularly (3 times or minimum twice) visit the applicant. If they fail to keep this promise, the inmate can be removed from the unit. It is not among the requirements that the applicants have to consider themselves religious or actually be religious. It is impossible to judge who really believes and who claims to be a believer without internal commitment. It is enough to have the intention to be admitted to the units and to accept the rules, the daily routine set by the head of the institution, and the "Regula". The religious faith is only one out of the possible aims. At the state's end it is an important aim because they expect the person's values to change if they take part in religious events.

There are many points where the regulations can be criticised. On the one hand because of the freedom of religion and its practice it is unjustified and raises constitutional concerns that difference is made between inmates based on the length of time left from their stay at the institution. It is unjustified because the social goal is to achieve a long-term and thorough change in the person's values. This kind of change quite often takes a longer time. The longer one has to adapt to the values around them, the more likely these values will become the part of their personality. This statement is true about both the values that are harmful and useful for the society. In accordance with 
this the longer the sentence, the greater influence prison life has on the personality. Literature is quite homogeneous related to this question concluding that this effect is against the aims of the reintegration. The goal is exactly the opposite: to let the person face the least harmful influences and for the least time possible. On the other hand, it is desirable to let the widely accepted and useful values affect people's personality intensively and for the longest time possible. Therefore, the use of this time limit is absolutely incomprehensible because it is against efficiency. The regulator may have put the emphasis on the period before the release because the relatively open unit can help inmates to prepare for freedom. Even if it is true, time limit is not the appropriate tool. The reasonable enhancement of the religious units and the chaplainship would be a better option because this way the religious values and the family ties would not prevail only in the period before being released from prison. The regulation raises constitutional issues, too, as the leftover of a sentence cannot reason for controlling the practice of a religion for people with the same rights in a different way. The leftover of a prison sentence cannot be the legitimate restraint of religious freedom. It is beyond dispute that the people in the religious or APAC units are in a more advantageous situation in terms of practising their religion. If the length of the imprisonment is a factor, then the person who has the longer sentence gets into a less advantageous situation as a consequence of this and falls under stricter control regarding their spiritual life.

The regulation in question seems to suggest that being admitted to the religious unit is practically an advantage that inmates may gain. The other critical remark is about the recommendation on the use of reintegration officers. By saying this the regulator creates a situation in which the employee of the neutral state can overrule the person's spiritual needs. Accepting that the order of the correctional institution must be maintained, it appears reasonable that the chaplain's opinion must be taken into account but the Admittance and Imprisonment Committee can come to a different conclusion to protect the order and safety of the institution. Finally, taking the type of crime committed into consideration does not seem to be justified either. It would easily make people think there is no conversion from each crime, not everyone can be healed. The original APAC intentionally does not take the crime committed into account. This would give the fake image of only concentrating on the easy cases and selecting perpetrators based on how great change is likely to happen considering the crime and their criminal record. By doing this people would restrict God's mercy saying a petty crime can be forgiven but serious crimes cannot or those people's souls who are "only a little bit" criminals can be changed but serious criminals are hopeless. So this solution is in a theological contradiction with the way the Hungarian regulations establish the APAC units.

It is true about each and every religious sector that reintegration is carried out by conveying Christian values. It is also a speciality that inmates receive continuous spiritual support and the prison provides opportunities for religious events where they can take part accompanied by their relatives or approved contacts. These events do 
not count as visits according to the prison regime rules. ${ }^{19}$ The aims include the maintenance and pampering of family relationships as this is one of the most significant factors that helps to avoid recidivism. ${ }^{20}$ The methods of spiritual support include programmes based on Christian values (Bible club, series of lectures, praying together, liturgical group meetings, film club, choir), meetings held by the chaplain, family church services, ad hoc and regular occasions for religious practice with the assistance of volunteers, religious programmes and events inside and outside the prison that aim at crime prevention and restoration, and meetings with former inmates of the unit to serve as a good example. The set of tools is not particularly reintegration aimed because most of them can be found in the regular church life alike. These type of religious events have been tailored to prisons. The interview with the chaplain recorded during my field visits at Szombathely National Prison shows that on the church side running the units does not aim at reintegration but rather take it as evangelism at an utmost special venue and for people in a special life situation. ${ }^{21}$ After this they let the inmates choose whether they bring the life-changing decision that is called conversion in theology or not. The Vác APAC units appear to be much more "personal". The chaplain here does not consider his service to be pure evangelism but in his role he takes on the tasks of education and reintegration. The chaplain in the Pálhalma APAC also defines his services as evangelism. In his point of view, he does not pursue reintegration, his aims and the penitentiary goal only meet if the inmate adapts himself/herself to society and as its valuable member does not commit more crime as a result of his/her conversion. The only positive difference compared with Szombathely is that the chaplain here feels responsible for the people living there, keeping an eye on their life, family relations while they are in the institution. However, this is rather a difference in the attitude and not the taxonomy.

The way a religious sector looks is different from the regular and strives to show the signs of "normal" life in its symbolism. In order to achieve this the cells are relatively homely, as much as possible in a prison setting. They are trying to avoid bunk beds if possible. It does not only make the place more tolerable but results in reducing the number of conflicts as recuperandos do not have dominance fights for the lower beds. They can even decorate the walls. Colourful walls and covers are allowed. Furthermore, the inmates can keep musical instruments and reliquiae in their cells. All of these possibilities serve the aim of having more human accommodation which facilitate becoming a better person. Besides this, those who live here really appreciate the opportunity they received. In the course of my site visits I found that the difference was significant between the religious units in Szombathely and the APAC in Vác. While the looks and the equipment of the former did not really differ from the other units of the institution,

\footnotetext{
19 Bv. tv. 109/A §. (3) par. (Penitentiary Code).

20 In an interview in one of my former researches the chaplain concluded that the greatest distracting power is the family. Those who experience how good it is to be a part of a family will take care of this value and do everything to be out of prison.

21 See also Tihanyi.
} 
the latter was a very pleasant spot in the dingy environment demonstrating that the sector was different from the others.

I would like to highlight one more dissimilarity between religious or APAC units and the original APAC concept. The total lack of police is typical of APACs. In our national circumstances it is hard to imagine this grade of trust and the internal selfadministration. At the same time, therefore, the educational aim which would serve to increase the person's responsibility is hurt. One of the groundbreaking features of the original APAC is the assistance of civilians. On the one hand they help recuperandos to maintain the order, on the other hand substitute tutors and instructors. The cooperation with civilians in Hungarian religious units or APACs is not comparable with the examples in Latin America. Even the most active civilian partner, the Hungarian Prison Community and Brotherhood takes part in the work only occasionally. It is true though, that they are still much more active than any other public organisation and they really take pains over APACs. This can be considered natural as the Community is the engine for the APACs in Hungary.

The rules of how security and order is maintained do not differ from the general rules but the set of tools is special and differentiated. The scale of sanctions on hand is as follows: 1. Interview with the personal reintegration officer, chaplain, or psychologist. 2. One-to-one or group training. 3. Case elaborating with the tools of drama pedagogy. 4. Conflict management. 5. Mediation. 6. Relocation within the sector. 7. Warning. 8. Initiation of disciplinary action. 9. Initiation of removal from the sector. Experiences show that the most rigorous sanction is very rarely used. All the chaplains that were asked replied that the reason for this is that the recoperandos have the most freedom, they can have the most contact with their families, and the number of conflicts are the lowest here.

The regulator defines the reasons for being removed from the unit as follows: 1. While staying in the unit serving their sentence criminal proceedings are started against the convict. 2. The convict commits serious or repeated disciplinary offence. 3. The convict does not follow the operational rules of the religious unit. Essentially, this is the same as breaking the rules in the "Regula". 4. Finally, the convict expressed his/her intention to leave the unit in a written form. ${ }^{22}$ The further criminal proceedings as a reason for being dismissed from the units shows that being accommodated there does not only mean that one can practice his/her constitutional rights and have a better chance for reintegration but it is a privilege, a reward. It is also worth emphasising that the well-established suspicion of a new crime is enough to be expelled. This circumstance raises the question of breaching the presumption of innocence. On the other hand, the time of the new crime is defined in a way that the suspicion of a crime committed before being placed at the units also results in being removed. Instead of this it would be a more satisfactory solution if the regulator only took it into account if the suspicion occurred after becoming a recuperando in the units. The form of the

22 Bv. tv. 109/A § (4) par. (Penitentiary Code). 
crime is not specified either. This lets us suspect that crimes committed out of recklessness or negligence (for example endangerment in connection with work) have the same consequence and the person is removed from the units. We could be entitled to challenge the fairness of this.

Unfortunately, there is no real difference between religious and APAC units in Hungary; they both mean a special unit of the penitentiary system. There appears to be two exceptions from the general rules. One is the intensive practice of religion, the other is the relatively close family contact. However, this does not come up to the maintenance of strong family relations as defined in the original APAC approach. We do not see the extensive presence of civilians. Neither the selection system, nor the promotional system can be identified. We can conclude that units in Hungary have very little in common with the ones in Brazil. However, we cannot claim that they do not have uniquely Christian goals and instruments based on which they are rightfully differentiated from any other units. We can conclude after this short introduction that there are a lot of possibilities for improvement in the future.

\section{References}

Burnside, Jonathan - Loucks, Nancy - Adler, Joanna R. - Rose, Gerry (2011): My Brother's Keeper. New York, Routledge.

Draxler Ferenc (2013): APAC körlet a Váci Fegyház és Börtönben. Börtönügyi Szemle, No. 4. 57.

Liebmann, Marian (2011): Restorative justice in prisons - An international perspective. Available: http://www.foresee.hu/uploads/media/MarianLiebmann_text.pdf/(Downloaded: 01.03.2018.)

Roszík Gábor (1998): A szeretet nem luxus. Börtönügyi Szemle, No. 1.

Sabbatelli, Maria Rosa (2015): APAC: an alternative model in the Brazilian penitentiary system. Available: http://www.europarl.europa.eu/meetdocs/2014_2019/documents/d-br/dv/03_note_on_ apac_ep_visit_/03_note_on_apac_ep_visit_en.pdf / (Downloaded: 11.02.2018.)

Takács Péter (s. a.): APAC. Manuscript. 6.

Tihanyi Miklós (s. a.): A Börtönlelkészi Szolgálat múködése. Iustum Aequum Salutare, Publication in progress. 